\title{
STRATEGI KESANTUNAN BAHASA BUGIS DALAM TINDAK TUTUR MEMERINTAH DI DESA LAMATA KECAMATAN GILIRENGKABUPATEN WAJO
}

\author{
Mualiyah Aznawi ${ }^{1}$ Safriwana Aras ${ }^{2}$ \\ Pendidikan Bahasa dan Sastra Indonesia, Universitas Muhammadiyah Makassar \\ mualiyah.asnawi@gmail.com \\ Pendidikan Bahasa dan Sastra Indonesia, Universitas Muhammadiyah Makassar \\ safriwana.a@gmail.co.id
}

\begin{abstract}
The main problem in this research is to know the language of politeness strategies Bugis in speech acts govern, as well as forms of politeness marker used in Bugis Village District of Gilireng Wajo Lamata. This study aims to determine strategies and forms of politeness marker Bugis language in speech acts govern in the Village District of Gilireng Wajo salvation. This research was a qualitative descriptive study, which emphasizes the use of data obtained from the field. A research procedure that produces descriptive data in the form of words written or spoken of the people observed. This research data was data Bugis village District of Gilireng Wajo Lamata, and includes verbal or speech or writing or text civility in speech acts govern. Data analysis did through several stages: observation of data, data identification, classification and categorization of data and markers politeness strategies based on their characteristics. The results showed that the Bugis language Politeness Strategies In Speech Acts Ruling In the village of the District Lamata Gilireng Wajo the strategy explicitly include: ordered, requested, forbid, permit, encourage, suggest, expect, propose options, invited, invite and urge. As well as the implicit strategy that includes: melaran, ordering, ask for help, encourage / persuade, urge and beg / permissions
\end{abstract}

Keywords: Strategy, politeness and speech acts.

Abstrak
Masalah utama dalam penelitian ini yaitu mengetahui strategi kesantunan bahasa Bugis
dalam tindak tutur memerintah, serta bentuk pemarkah kesantunan yang digunakan dalam
bahasa Bugis di Desa Lamata Kecamatan Gilireng Kabupaten Wajo. Penelitian ini
bertujuan untuk mengetahui strategi dan bentuk pemarkah kesantunan bahasa Bugis
dalam tindak tutur memerintah di Desa Lamatan Kecamatan Gilireng Kabupaten Wajo.
Penelitian ini merupakan jenis penelitian yang bersifat deskriptif kualitatif, yang
menekankan pada penggunaan data yang diperoleh dari lapangan. Prosedur penelitian
yang menghasilkan data deskriptif berupa kata-kata tertulis atau lisan dari masyarakat
yang diamati. Data penelitian ini adalah data bahasa Bugis di desa Lamata Kecamatan
Gilireng Kabupaten Wajo baik yang berupa lisan atau tuturan maupun tulisan atau teks
kesantunan dalam tindak tutur memerintah. Teknik analisis data yang dilakukan melalui
beberapa tahapan yaitu: observasi data, identifikasi data, klasifikasi data dan
pengkategorian strategi dan pemarkah kesantunan berdasarkan karakteristiknya. Hasil
penelitian menunjukkan bahwa Strategi Kesantunan Bahasa Bugis Dalam Tindak Tutur
Memerintah Di Desa Lamata Kecamatan Gilireng Kabupaten Wajo yaitu strategi secara 
eksplisit yang meliputi: menyuruh, meminta, melarang, mengizinkan, mengimbau, menganjurkan, mengharapkan, mengajukan pilihan, mempersilakan, mengajak dan mendesak. Serta strategi secara implisit yang meliputi: melaran, menyuruh, meminta bantuan, mengimbau/mengajak, mendesak, dan memohon/permisi

Kata kunci: Strategi, kesantunan dan tindak tutur.

\section{PENDAHULUAN}

Bahasa merupakan salah satu sarana untuk berinteraksi dalam lingkungan sosial. Untuk kepentingan interaksi sosial dibutuhkanlah bahasa sebagai alat berkomunikasi. Dengan bantuan bahasa, interaksi sosial antara masyarakat yang satu dengan masyarakat yang lain akan berlangsung dengan baik. Hal ini pun menjadi penanda bahwa terwujudnya kompetensi atau kemampuan berkomunikasi tidak lain karena adanya korelasi psikologis suatu bahasa.

Apabila fungsi bahasa dilihat dari konsep tindak tutur (speech act), fungsi bahasa dapat digunakan untuk melakukan sesuatu. Dengan kata lain, suatu ujaran tidak hanya dapat dinilai dengan benar atau tidak benarnya, tetapi juga dari kesahihan tuturan tersebut. Untuk menilai benar salahnya sebuah tuturan, hal itu tidak dapat dipisahkan dari situasi tutur (speech situation), dan peristiwa tutur (speech event), yang berada dalam suatu masyarakat tutur (the speech community), yaitu suatu komunitas atau masyarakat yang memiliki pengetahuan bersama tentang norma tutur, baik dalam bertutur ataupun dalam menginterpretasikannya.

Berdasarkan tahun terakhir ini kajian kesantunan berbahasa telah menjadi salah satu aspek yang banyak diperhatikan. Hal ini disebabkan munculnya indikasi semakin menurunnya derajat kesantunan berbahasa dalam suatu masyarakat. Indikasi ini dapat menjadi penanda timbulnya pergeseran perilaku berbahasa, khususnya kesantunan berbahasa dari generasi ke generasi. Fonemena ini pun menjadi hal yang prioritas untuk segera dientaskan mengingat lambat laun gejala ini akan semakin terpola dan merusak jaringan komunikasi yang beretika.

Salah satu aspek tindak tutur yang mengutamakan kesantunan adalah tindak tutur memerintah. Tindak tutur memerintah merupakan salah satu tindakan yang dilakukan agar mitratutur dapat melaksanakan permintaan, suruhan, atau perintah dari penutur. Untuk mencapai tujuan sebagaimana yang diinginkan oleh penutur, biasanya digunakan beberapa strategi agar perintah tersebut dapat berterima baik oleh mitratutur.

jika pemenuhan atas pemanfaatan strategi tidak terjadi, maka hubungan antara penutur dan mitratutur menjadi tidak seimbang, padahal interaksi sosial akan dapat berjalan harmonis jika prinsip kerjasama dan keseimbangan diterapkan. Itulah sebabnya, jalinan komunikasi dan hubungan sosial kedua belah pihak perlu diperbaiki melalui ungkapan memerintah sesantun mungkin. Salah satu cara untuk mencapai tujuan ini, penutur perlu menggunakan pemarkah kesantunan dan memilih strategi untuk mengungkapkan perintahnya, yang biasanya dilakukan melalui studi kebiasaan yang berlaku dalam masyarakat setempat, yang dapat menghasilkan pola strategi berbahasa yang dianggap pantas berdasarkan konteks budaya yang berlaku.

Demikian halnya yang terjadi pada bahasa Bugis, dipercaya terdapat beberapa pola atau strategi yang dapat diterapkan untuk mencapai tujuan dan menghindari kesalahpahaman antara penutur dan mitratutur serta menjunjung tinggi kesantunan dalam berbahasa di masyarakat. 


\section{Tentang Tindak Tutur}

\subsection{Pengertian Tindak Tutur}

Dalam bukunya How to Do Things with Words, Austin (1962) menyatakan bahwa bahasa tidak hanya digunakan untuk menyatakan sesuatu, tetapi juga dapat digunakan untuk melakukan suatu tindakan. Menurut pakar ini, suatu tuturan bukan hanya digunakan untuk menyatakan suatu hal, melainkan juga untuk mengungkapkan sikap, perasaan, dan juga maksud penutur. Ahli lain, Sumarsono (2002:323) mengatakan bahwa tindak tutur adalah sepenggal tutur yang dihasilkan sebagai bagian dari interaksi sosial.

Harnida (2012) tindak tutur (speech art) merupakan unsur pragmatik yang melibatkan pembicara, pendengar, penulis, pembaca serta yang dibicarakan. Dalam penerapannya tindak tutur digunakan oleh beberapa disiplin ilmu. Harnida (dalam Chaer 2004:16) menyatakan tindak tutur merupakan gejala individual, bersifat psikologis dan keberlangsungannya ditentukan oleh kemampuan bahasa si penutur dalam menghadapi situasi tertentu.

Akbar (2014: 9) tindak tutur merupakan analisis pragmatik, yaitu cabang ilmu bahasa yang mengkaji bahasa dari aspek pemakaian aktualnya. Tindak tutur juga dapat dikatakan sebagai salah satu kegiatan fungsional manusia sebagai makhluk berbahasa. Akbar (dalam Leech:1983: 5-6) menyatakan bahwa pragmatik mempelajari maksud ujaran (yaitu untuk apa ujaran itu dilakukan); menanyakan apa yang seseorang maksudkan dengan suatu tindak tutur; dan mengaitkan makna dengan siapa berbicara kepada siapa, di mana, bilamana, bagaimana. Tindak tutur merupakan entitas yang bersifat sentral di dalam pragmatik dan juga merupakan dasar bagi analisis topik-topik lain di bidang ini seperti praanggapan, perikutan, implikatur percakapan, prinsip kerjasama dan prinsip kesantunan.

Berdasarkan beberapa pendapat tersebut dapat disimpulkan bahwa tindak tutur adalah suatu tindakan bertutur yang memiliki maksud tertentu yang dapat diungkapkan secara eksplisit maupun implisit. Tindak tutur yang memiliki maksud tertentu tersebut tidak dapat dipisahkan dari konsep situasi tutur. Konsep tersebut memperjelas pengertian tindak tutur sebagai suatu tindakan yang menghasilkan tuturan sebagai produk tindak tutur.

\subsection{Strategi Tindak Tutur Memerintah dalam Bahasa Bugis}

Menurut Djajasudarman (dalam Hasbia 2012), strategi tindak ujar/tutur dapat diklasifikasikan ke dalam tindak tutur langsung (direct speech acts) dan tindak tutur tak langsung (inderct speech acts). Tindak tutur langsung menunnjukkan fungsinya dalam keadaan (tindakan) langsung dan literal (penuturab sesuai dengan kenyataan) sedangkan tindak tutur tidak langsung biasanya diidentifikasikan dengan kalimat performatif yang implisit.

Sebagai realisasi atas strategi memerintah maka tuturan dalam tindakan memerintah yang ditemukan dalam bagian ini merupakan tuturan asli dalam bentuk perintah, baik perintah secara eksplisit maupun secara implisit yang ditemui di lapangan tanpa melalui penyuntingan data. Selain itu, sampel data yang ditampilkan juga telah dikelompokkan ke dalam beberapa strategi, baik strategi memerintah secara langsung (eksplisit) maupun strategi secara tidak langsung (implisit) beserta substrateginya masingmasing.

\subsubsection{Strategi Memerintah Secara Eksplisit}

Tuturan memerintah secara langsung terbentuk dari kalimat perintah. Kalimat perintah ini umumnya berjenis 
kalimat elips karena hanya terdiri atas satu kata ataupun kelompok kata yang berkategori verba. Di samping itu, ada pula tuturan yang muncul dengan verba atau nomina, tetapi diikuti oleh kata sapaan, bentuk honorifik atau kategori fatis sebagai piranti penanda daya ilokusinya.

\section{a. Strategi Memerintah Secara}

Eksplisit dengan Maksud Menyuruh Strategi memerintah secara ekplisit ini digunakan untuk merealisasikan tuturan perintah penutur kepada mitratutur dengan maksud menyuruh. Strategi ini dipilih oleh penutur agar mitratutur juga dapat dengan langsung memenuhi perintah suruhan penutur. Dalam penggunaan strategi ini, kecuali ditemukan tuturan yang kadar sangat rendah.

\section{b. Strategi Memerintah Secara \\ Eksplisit dengan Maksud Meminta} Strategi memerintah secara eksplisit yang diwujudkan dalam bentuk meminta, lebih banyak digunakan oleh penutur. Selain untuk lebih memudahkan kemungkinan terjadinya kerjasama lebih tinggi antara penutur dan mitra tutur juga bertujuan untuk meminta bantuan atau perhatian mitra tutur agar segera mungkin memenuhi permintaan mitratutur.

\section{c. Strategi Memerintah Secara eksplisit dengan Maksud Melarang}

$\begin{array}{cclr}\text { Strategi } & \begin{array}{l}\text { memerintah } \\ \text { ekplisit in secara }\end{array} \\ \text { digunakan } & \text { untuuk }\end{array}$ merealisasikan tuturan perintah penutur kepada mitratutur dengan maksud melarang. Strategi ini dipilih oleh penutur agar mitratutur juga dapat dengan langsung memenuhi perintah larangan penutur. Dalam bahasa Bugis keseharian ungkapan memerintah yang bermaksud melarang ini selain ditemukan dalam kadar kesantunan yang tinggi ada pula yang memiliki kadar kesantunan yang rendah. Hal itu bergantung pada konteks dan situasi pertuturan yang melatarinya.

\section{d. Strategi Memerintah Secara Ekplisit dengan Maksud Mengizinkan}

$\begin{array}{rrrr} & \text { Strategi } & \text { memerintah } & \text { secara } \\ \text { ekplisit ini } & \text { digunakan } & \text { untuk }\end{array}$ merealisasikan tuturan perintah penutur kepada mitratutur dengan maksud memenuhi permintaan mitratutur. Dalam bahasa Bugis keseharian ungkapan memerintah yang bermaksud mengizinkan ini selain ditemukan dalam kadar kesantunan yang tinggi, adapula yang memiliki kadar kesantunan yang rendah. Hal ini bergantung pada konteks dan situasi pertuturan yang menyertainya.

e. Strategi Memerintah Secara Ekplisit dengan Maksud

\section{Menyarankan/Mengimbau}

Strategi memerintah secara ekplisit ini digunakan untuk merealisasikan tuturan perintah penutur kepada mitratutur dengan maksud memberikan saran atau imbauan kepada mitratutur. Dalam bahasa Bugis keseharian ungkapan memerintah yang bermaksud menyarankan ini selain ditemukan dalam kadar kesantunan yang tinggi, ada pula yang memiliki kadar kesantunan yang rendah.

\section{f. Strategi Memerintah Secara Ekplisit dengan Maksud Menganjurkan}

Strategi memerintah secara ekplisit dan bermaksud menganjurkan ini, sesungguhnya tidak berbeda jauh dengan strategi memerintah yang bermaksud menyarankan atau mengimbau. Pada bahasa Bugis, strategi ini umumnya menggunakan kata madeceng kapang 'mungkin lebih baik', mabello kapang 'sebaiknya/ mungkin lebih bagus' yang berfungsi sebagai pemarkah kesantunan.

\section{g. Strategi Memerintah Secara Ekplisit dengan Maksud Mengharapkan}

ekplisit ini digunakan untuk merealisasikan tuturan perintah penutur kepada mitratutur dengan maksud mengharapkan. Strategi ini dipilih oleh penutur agar mitratutur juga dapat dengan 
langsung memenuhi perintah sekaligus harapan penutur. Dalam bahasa Bugis mumnya strategi memerintah dengan tujuan mengharapkan ini dicirikan oleh frasa verba yang bermakna pengharapan, misalnya: upiminasakik, urennuakkik, uharapkik, tennapodo, mammuarekgi..

Beberapa alasan penutur memilih strategi memerintah yang bertujuan mengharapkan ini, antra lain agar ungkapan memerintah si penutur terkesan lebih halus dan santun, dapat leebih mudah berterima dan direspon oleh mitratutur, berusaha menjaga citra positif dan mengurangi ketersinggungan mitratutur.

\section{h. Strategi Memerintah Secara Ekplisit dengan Maksud Mengajukan Pilihan}

Untuk merealisasikan tuturan perintah kepada mitratutur biasanya penutur memilih strategi memerintah secara ekplisit dengan mengajukan pilihan kepada mitratutur. Selain memerintah langsung, strategi ini juga bertujuan memberikan pilihan kepada mitratutur di antara dua klausa yang bermakna perintah. Pemarkah kesantunan pada bahasa Bugis yang biasa digunakan penutur dalam menerapkan strategi ini adalah iyare'ga dan atau sendiri. Keduanya bermakna 'atau'.

Beberapa alasan penutur memilih strategi memerintah yang bertujuan memberikan pilihan kepada mitratutur ini, selain agar ungkapan memerintah tersebut dimaknai lebih halus dan santun, dapat lebih mudah berterima dan direspon oleh mitratutur, juga merupakan usaha penutur dalam mempertahankan muka positif (positive face) mitratuturnya.

i. Strategi Memerintah Secara Ekplisit dengan Maksud Mempersilakan

$\begin{array}{rrrr} & \text { Strategi memerintah } & \text { secara } \\ \text { ekplisit ini } & \text { digunakan untuk }\end{array}$ merealisasikan tuturan perintah penutur kepada mitratutur dengan maksud mempersilahkan mitratutur melakukan kegiatan sesuai yang diperintahkan oleh penutur. Dengan menggunakan pemarkah tabéq 'maaf' dalam bahasa Bugis, ungkapan memerintah tersebut semakin berterima karena dianggap sebagai tuturan yang santun dan beretika, sekaligus merupakan strategi bertutur yang paling banyak dipilih penutur. Dalam bahasa Bugis keseharian ungkapan memerintah yang bermaksud mempersilahkan ini umumnya ditemukan dalam bentuk tuturan yang memiliki nilai kesantunan yang tinggi.

\section{j. Strategi Memerintah Secara Ekplisit dengan Maksud Mengajak}

Bentuk ungkapan memerintah dengan strategi mengajak ini, dipilih oleh penutur dengan perimbangan agar mitratutur tidak merasa diperintah langsung oleh penutur. Pemarkah kesantunan memerintah yang bermakna mengajak, terealisasai delam bentuk verba yang digunakan dan digukung pula oleh penggunaan pemarkah kesantunan bahasa Bugis yang lebih umum. Penggunaan verba yang dimaksud adalah verba performatif, yaitu penggunaan kata berkategori verba yang bermakna mengajak. Misalnya dalam bahasa Bugis, ditemui dalam bentuk verba aktif létténik 'marilah', lokkanik 'ayolah berangkat', réwéknik 'ayo kita pulang!

\section{k. Strategi Memerintah Secara Ekplisit dengan Maksud Mendesak}

Ungkapan memerintah dengan maksud mendesak, ditemukan pada penutur yang memiliki kekuasaan, keotortasan, hubungan kekerabatan, dan status sosial lebih tinggi dari pada mitratutur. Penutur memberikan desakan kepada mitratutur agar sesegera mungkin menjalankan perintah yang diperintahkan.

\subsubsection{Strategi Memerintah Secara Implisit}

Selain ungkapan memerintah yang direalisasikan dalam bentuk ekplisit, adapula ungkapan memerintah yang direalisasikan dalam implisit. Tak berbeda 
dengan ungkapan memerintah secara ekplisit, ungkapan memerintah secara implisit pun ditemui dalm bentuk kalimat yang panjang atau kalimat elips.

Pada ungkapan langsung bentuk tuturan yang diungkapkan oleh penutur cenderung menggunakan kata yang beraposisi dengan verba pervormatif. Umumnya kalimat yang digunakan tidak mesti dalam bentuk kalimat deklaratif dan iperatif, tetapi ditemui pula dalam bentuk kalimat lain, seperti kalimat interogatif. Namun demikan, maksud kalimat itu tetap marifer atau mengacu pada maksud yang yang sesuai dengan bentuk ekplisit. Strategi implisit ini dipilih oleh penutur dengan pertimbangan pada pengutamaan menjaga harga diri dan kehormatan, mappakaraja dan mappakalebb-i mitratutur.

Dipercaya dengan tetap menjaga muka positif (positive face) mitratutur, hubungan yang harmonis antara kedua partisipan tersebut akan semakin baik. Berikut ini adalah bentuk ungkapan memerintah secara implisit yang dituturkan oleh penutur dalam berbagai strategi dan substrategi:

\section{a. Strategi Memerintah Secara Implisit dengan Maksud Melarang}

Dalam mengungkapkan maksud memerintahnya, penutur kadangkala menggunakan strategi memerintah secara implisit, termasuk agar keinginan penutur dapat berterima oleh mitratutur melakukan pekerjaan yang membahayakan partisipan. Untuk menyamarkan ungkapan memerintahya maka penutur menggunakan strategi memerintah dengan kalimat yang memiliki makna oposisi dengan perintah sebenarnya, tetapi tetap memiliki makna yang sama.

\section{b. Strategi Memerintah Secara Implisit dengan Maksud Menyuruh

$\begin{array}{rrr}\text { Strategi memerintah } & \text { secara } \\ \text { implisit ini digunakan } & \text { untuk } \\ \text { merealisasikan tuturan perintah } & \text { penutur }\end{array}$

kepada mitratutur dengan maksud menyuruh. Strategi ini dipilih oleh penutur agar mitratutur juga dapat dengan langsung memenuhi perintah suruhan penutur. Dalam penggunaan strategi ini ungkapan memerintah biasanya digunakan hanya dengan menyebutkan objek atau subjek yang berkategori kata benda, kata kerja atau kata sifat saja. Strategi ini cukup banyak digunakan oleh penutur dalam mengungkapkan perintahnya, karena dianggap lebih sederhana. Agar terjalin kerjasama antara penutur dan mitratutur, maka keduanya harus memahami konteks tuturan.

\section{c. Strategi Memerintah Secara Implisit dengan Maksud Meminta Bantuan}

Selain itu, khusus pada ungkapan secara tidak langsung ini ditemukan beberapa ungkapan memerintah yang bermaksud meminta bantuan yang disamarkan dengan memberikan penjelasan situasi yang melatari konteks. Ungkapan memerintah dengan strategi ini dipilih oleh penutur dengan maksud mengimplisitkan ungkapan memerintah.

Beberapa alasan penutur memilih strategi memerintah yang bertujuan meminta bantuan ini. Selain agar ungkapan memerintah tersebut dimaknai lebih halus dan santun, dapat lebih mudah berterima dan direspon oleh mitratutur, juga merupakan usaha penutur dalam mempertahankan muka (positive face) positif mitratuturnya.

Intonasi merupakan salah satu strategi yang digunakan untuk memperhalus tuturan memerintah seseorang di samping gerak tubuh atau isyarat tubuh penutur. Semakin tinggi dan keras intonasi perintah penutur, semakin tidak santun pula tuturan itu. Sebaliknya, semakin rendah dan lembut intonasi perintah penutur, semakin santun pula tuturan itu.

\section{d. Strategi Memerintah Secara Implisit dengan Maksud Mengimbau/ Menganjurkan/ Mendesak}


Pemilihan strategi yang dapat bermakna mengimbau, atau menganjurkan atau mendesak ini dimaksudkan untuk memperkecil ketersinggungan dan keterancaman muka mitratutur. Melalui ungkapan memerintah yang implisit diharapkan penutur telah berusaha memberikan pencitraan yang baik kepada mitratutur.

Bagi masyarakat penutur bahasa Bugis, ungkapan memerintah secara implisit lebih sering digunakan. Hal ini dipengaruhi faktor pemahaman yang konvensional, bahwa jika sebuah ungkapan perintah yang dituturkan secara langsung, maka kadar kesantunan tuturan itu sangat rendah. Sebaliknya jika ungkapan itu dituturkan secara implisit (tidak langsung), maka tuturan itu memiliki kadar kesantunan yang tinggi. Tentunya hal tersebut berhubungan dengan usaha menyelamatan muka partsipan masing-masing.

e. Strategi Memerintah Secara Implisit dengan Maksud Memohon/Permisi

Strategi memerintah secara implisit yang diwujudkan dalam bentuk memohon/permisi lebih banyak digunakan oleh penutur dengan hanya menggunakan verba performatif, yaitu verba yang mengacu pada inti perintah tersebut. Selain itu, penutur lebih banyak menggunakan pemarkah kesantunan saja, ditambah dengan gerakan tubuh. Pemarkah yang dimaksud tersebut dalam bahasa Bugis yaitu; addampengekka (maafkan saya), tulungngak (tolong), tabéq (maaf).

4. Bentuk-bentuk Pemarkah Kesantunan dalam Tindak Tutur Memerintah

Agar maksud penutur dapat diterima sesuai keinginannya tanpa mengancam muka kedua belah pihak, sebagian besar penutur memilih kesantunan berbahasa sebagai perwujudan dari strategi tindak tutur. Demikian halnya pada tindak tutur memerintah, penutur menggunakan beberapa strategi dalam mengungkapkan kesantunan kepada mitratutur melalui ungkapan perintahnya.

Masyarakat tutur yang ada di Kabupaten Wajo sangat menjunjung tinggi nilai kesopanan. Hal ini dapat diukur dengan tingginya kadar kesantunan dalam bertindak dan bertutur, khususnya pada ungkapan memerintah yang kadaritasnya dapat diukur melalui penggunaan pemarkah-pemarkah kesantunan yang sifatnya konvensional dan telah diatur dalam sistem berbahasa masyarakat Bugis. Kecuali itu, masyarakat tutur yang ada di Kabupaten Wajo sangat menjunjung tinggi dan menghormati ajaran adat Bugis-Makassar yang tercermin dalam konsep sipakatau dan sipakalebbi, yaitu menjunjung tinggi persaudaraan dengan mengutamakan penghargaan dan penghormatan kepada sesama manusia. Ajaran ini tidak terlepas dari budi pekerti seseorang, yaitu adanya rasa, perasaan, malu (siri') dan kesopanan. Berdasarkan ajaran adat tersebut, dapat diketahui bahwa ungkapan memerintah sebagai sebuah bentuk kesantunan berbahasa telah terajarkan secara hakiki dalam ajaran adat BugisMakassar. Konsep malu yang berkaitan dengan muka dan kesantunan dalam berbahasa juga tercakup dalam konsep malu dan sopan. Bagaimanapun budi pekerti yang baik digunakan antara lain untuk membangun gubungan baik antara manusia.

\section{METODE PENELITIAN}

a. Rancangan Penelitian

Jenis penelitian ini adalah penelitian kualitatif deskriptif. Penelitian kualitatif deskriptif bertujuan untuk mengungkapkan berbagai informasi kualitatif dengan pendeskripsian yang teliti dan penuh nuansa untuk menggambarkan secara cermat sifat-sifat suatu hal (indivudu atau kelompok), keadaan, gejala, atau fenomena yang lebih 
berharga daripada hanya pernyataan dalam bentuk angka-angka dan tidak terbatas pada pengumpulan data melainkan meliputi analisis dan interpretasi data.

\section{b. Fokus Penelitian}

Fokus dari penelitian ini adalah strategi kesantunan bahasa Bugis dalam tindak tutur memerintah yang digunakan oleh penutur Bugis di Desa Lamata, Kecamatan Gilireng, Kabupaten Wajo.

\section{c. Tempat dan Subjek Penelitian}

Peneliti bermaksud melakukan penelitian ini di Desa Lamata, Kecamatan Gilireng, Kabupaten Wajo. Adapun subjek penelitian ini yaitu masyarakat tutur dari desa tersebut.

\section{d. Data dan Sumber Data \\ 1. Data}

Data yang dikaji dalam penelitian ini adalah data bahasa Bugis di Desa Lamata, Kecamatan Gilireng, Kabupaten Wajo baik bahasa lisan atau tuturan maupun tulisan atau teks kesantunan dalam tindak tutur memerintah.

\section{Sumber Data}

Data yang akan dikaji dalam penelitian ini bersumber dari bahasa lisan dan bahasa tertulis, yaitu segenap tuturan yang diungkapkan oleh penutur di dalam masyarakat yang dianggap berimplikasi pada bentuk atau tindakan memerintah dalam bahasa Bugis di Desa Lamata, Kecamatan Gilireng, Kabupaten Wajo.

\section{$e$. Teknik Pengumpulan Data}

Untuk memperoleh data yang lengkap, peneliti menggunakan teknik yang dianggap relevan dengan tujjuan yang ingin dicapai. Antara lain: pengamatan langsung, teknik mencatat, teknik simak libat cakap.

\section{f. Teknik Analisis Data}

Teknik analisis data atau pengolahan data yang dilakukan untuk mengetahui strategi kesantunan dalam ungkapan memerintah dan bentuk pemarkah kesantunan yang digunakan dalam bahasa Bugis, dilakukan berdasarkan beberapa tahap yaitu: obsevasi data, identifikasi data, klasifikasi data, dan pengkategorian strategi dan pemarkah kesantunan berdasarkan karakteristiknya.

Adapun langkah-langkah yang penulis tempuh dalam menganalisis data adalah sebagai berikut:

1. Menerjemahkan arti bahasa Bugis (daerah) ke dalam bahasa Indonesia,

2. Mengelompokkan tuturan perintah berdasarkan strategi tindak tutur, dan

3. Menganalisis.

\section{HASIL PENELITIAN DAN PEMBAHASAN}

a. Hasil Penelitian

1. Strategi Memerintah Secara Eksplisit

\subsection{Memerintah Secara Eksplisit} dengan Maksud Menyuruh

(1) a. Tulungngak, Ndik. Tapamperengngak iyaro serok'e!

'Tolong saya Dik, ambilkan saya itu timba'

(Tolong saya Dik, ambilkan timba itu!)

b. Tabek Puang, Idikna ri olo!

'Maaf Puang, Anda saja

di depan!'

(Maaf Puang, Anda di

depan saja!)

c. Idikna palek tudang riolo,

Daeng!

'Anda saja kalau begitu duduk di depan, Kakak!'

(Kalau begitu, Kakak saja yang duduk di depan!)

(2) a. Tabukkarengngak garek pattutuk botolok e, Daeng!

'Kamu bukakan saya coba penutup botol ini, Kakak!'

(Kakak, coba bukakan penutup botol ini!)

b. Idikna Rahma jokka malawi emma! 
'Kamu saja Rahma pergi jemput mama!'

(Kamu saja Rahma yang menjemput mama!)

(3) a. Alammanak iyaro remok' e ko sideppemu!

'Ambilkan itu remot di dekat kamu!'

(Ambilkan remot itu di dektatmu !)

b. Jokkasaino melli bette lame, cappui matuk!

'Pergi saja kamu membeli ubi goreng, habis nanti!'

(Pergi sajalah kamu membeli ubi goreng, nanti habis!)

Dalam pemakaian bahasa Bugis keseharian, tuturan memerintah yang diwujudkan dalam bentuk memerintah secara langsung seperti pada tuturan (1-3) di atas dapat diketahui makna atau tujuannya melalui konteks dan situasi pertuturan yang melatarinya. Ungkapan memerintah pada tuturan tersebut dianggap memiliki kadar kesantunan yang lebih tinggi. Dengan menggunakan penanda daya ilokusi tulung 'tolong', tabek 'maaf', dan penunjuk persona pertama idik 'kamu/saudara' sebagai pelembut ujaran maka ungkapan perintah tersebut dapat dengan mudah berterima. Selain itu terdapat pula penanda daya ilokusi yang berupa kata penanda hubungan kekerabatan (penanda honorifik) dalam bahasa Bugis, Puang dan ndik.

Pada ungkapan memerintah (1a) tuturan tersebut terjadi di sekitar bak air. Ungkapan tersebut dituturkan oleh seorang ibu kepada seorang perempuan, dalam ungkapannya penutur menggunkan pemarkah kesantunan tulungngak 'tolong saya' dan penanda honorifik ndik 'dek' dengan tujuan agar mitratutur dengan senang hati mengambilkan serok 'timba' kepada penutur. Demikian halnya pada tuturan (1b) dan (1c). tuturan (1b) dituturkan oleh seorang bapak kepada bapak yang lain yang memiliki usia yang sedikit lebih tua dari dirinya, penutur menyuruh mitratutur agar duduk di depan dengan maksud mappakaraja (menghormati) mitratutur. Sementara itu tuturan (1c) yang dituturkan oleh seorang perempuan kepada kakaknya agar duduk berada di depan sebagai tanda penghormatan karena dalam kebiasaan masyarakat Bugis, orang yang dituakan atau dihormati biasanya disediakan tempat dibagian depan.

Dari penjelasan di atas dapat diketahui bahwa ungkapan memerintah pada tuturan (1), (2), dan (3) diurut berdasrkan kadar kesantunannya. Artinya, tuturan (1) lebih tinggi kadar kesantunannya daripada tuturan (2) dan (3). Demikian halnya tuturan (2) dianggap lebih santun daripada tuturan (3). Penentu kadar kesantunan tuturan-tuturan tersebut mengacu pada pemarkah kesantunan dan kategori fatis atau sesuai tidaknya penanda honorifik yang digunakan. Selain itu, situai yang melatari tuturan tersebut juga menjadi faktor pendukung kesantunan suatu tuturan.

Ungkapan memerintah pada (2a) memiliki kadar kesantunan yang sama dengan ungkapan pada (2b). Ungkapan pada (2a) dituturkan oleh seorang perempuan kepada kakaknya. Tuturan ini dianggap sebagai tuturan yang memiliki kadar kesantunan yang lebih tinggi karena penutur menggunakan menggunakan kategori fatis $t a$ - 'kamu' dan penanda honorifik daeng 'kakak' dengan maksud memperalus ungkapan perintahnya terhadap kakaknya.

Sementara itu, ungkapan memerintah dengan maksud menyuruh juga terdapat pada (3) yang dianggap sebagai tuturan memiliki kadar kesantunan yang rendah. Namun ungkapan (3a) memiliki kadar kesantunan yang sama pula dengan ungkapan (3b). Pada (3a) ungkapan yang dituturkan oleh seorang anak laki-laki kepada temannya 
yang memiliki umur yang lebih tua darinya. Penggunaan penanda kategori fatis - mu pada sideppemu 'dekat kamu'. Meskipun ungkapan ini dituturkan kepada temannya sendiri namun dapat dikatakan bahwa tuturan ini memiliki kadar kesantunan yang rendah karena mitratutur memiliki umur yang lebih tua daripada penutur. Lain halnya pada tuturan (3b) yang dituturkan oleh seorang adik kepada kakaknya dengan menggunakan penanda kategori fatis -no pada kata jokkasaino 'pergi sajalah kamu'. Dalam bahasa Bugis penggunaan penanda kategori fatis $-m u$ dan -no tersebut pada sebuah tuturan di masyarakat di Kabupaten Wajo khususnya di Desa Lamata Kecamatan Gilireng dianggap tidak santun atau dengan kata lain suatu tuturan dinilai memiliki kadar kesantunan yang rendah apabila menggunakan penanda kategori fatis $-m u$ dan - no.

\subsection{Memerintah Secara Eksplisit dengan Maksud Meminta}

(4) a. Taddampengekka Puang, idikmi uduppai baja lao ki bolae!

'Kamu maafkan saya Puang, Anda saya undang besok datang di rumah!'

(Saya mohon maaf Puang, Saya mengundang Anda datang ke rumah besok!)

b. Uolliko lao ki bolae baja narekko essoi!

'Saya panggil kamu pergi di rumah besok kalau siang!'

(Saya panggil kamu datang besok siang ke rumahku!)

(5) a. Tabek, idikna makkai sanggang $e$, Ndik!

'Maaf, Anda saja mengangkat baskom itu, Dek!

(Maaf Dek, Anda saja yang mengangkat baskom!)

b. oeee, ikona makkai sanggang $e$ na!

'Hai, Kamu saja angkat baskom ya!'
(Hai, Kamu saja yang angkat baskom ya!)

(6) a. Tulungkak Ndik, tatiwirengngak iyaro passerring e!

'Tolong saya Dek, kamu antarkan saya itu sapu!'

(Tolong Dek, kamu antarkan sapu itu!)

b. Tiwirengngak yolo iyaro passerring e!

'Kamu antarkan saya dulu itu sapu!'

(Antarkan saya sapu itu!)

Berdasarkan skala kesantunan, tuturan $(4 a, 5 a$, dan 6a) dianggap sebagai tuturan yang sesuai dengan etika berbahasa masyarakat Bugis di desa Lamata kecamatan Gilireng kabupaten Wajo. Pada ungkapan memerintah (4a) penutur bermaksud meminta atau memohon kepada mitratutur. Secara langsung penutur memerintahkan kepada mitratutur untuk datang ke rumahnya keesokan harinya. Salah satu strategi yang digunakan oleh penutur agar permohonan dapat terpenuhi dengan baik dan ungkapannya tidak menyinggung perasaan mitratuturnya, yang merupakan orang yang di segani di masyarakat setempat, penutur menggunakan pemarkah kesantunan taddampengekkak 'maafkanlah saya'. Demikian halnya pada ungkapan memerintah secara eksplisit pada tuturan (5a) dianggap sebagai tuturan yang beretika. Dalam tuturannya, penutur meminta kepada mitratutur, temannya yang berusia sebaya dengannya, agar mengangkat baskom yang ada di dekatnya. Agar tidak menyinggung perasaan temannya karena telah memerintahkan untuk mengangkat baskomnya, maka penutur menggunakan pemarkah kesantunan, tabek 'maaf'. Demikian pula halnya dengan tuturan (6a) Tulukkak Ndik, tatiwirekkak iyaro passerringnge! 'Tolong Dek, kamu antarkan sapu itu' dikategorikan sebagai tuturan yang santun.tuturan ini 
diungkapkan oleh seoorang kakak kepada adiknya. Penutur bermaksud meminta bantuan kepada mitratuturnya agar dapat mengantarkan sapu yang ada di dalam rumah dan kebetulan mitratutur tersebut juga berada di dalam rumah. Agar terkesan santun dan permintaan bantuan penutur direspon baik oleh mitratutur, penutur menggunakan pemarkah kesantunan tulung 'tolong'. Disamping itu, penutur juga menggunakan penanda honorifik ndik 'dek' dan kata yang berkategori fatis ta- 'kamu' yang berfungsi sebagai pelembut ujaran dan sebagai penghormatan.

Sangat berbeda dengan tuturan (4b,5b,dan 6b), sekalipun ungkapan memerintah tersebut memiliki maksud dan tujuan yang sama dengan tuturan (44a,5a,dan 6a) akan tetapi, karena diungkapkan dengan menggunakan strategi yang berbeda, maka tuturan tersebut dianggap sebagai ungkapan memerinntah yang yang memiliki kadar kesantunan yang rendah. Dalam bahasa Bugis khususnya di desa Lamata kecamatan Giliren kabupaten Wajo tuturan seperti ini dipengaruhi oleh situasi kebahasaan yang berlaku pada penutur dan mitratutur. Bagi penutur yang memiliki kekuasaan yang lebih tinggi, dan status atau kedudukan sosial yang lebih terhormat maka ungkapan seperti pada (4b,5b,dan 6b) merupakan tuturan yang wajar, apalagi bila dituturkan kepada mitratutur yang berstatus bawahan, serta tidak memiliki status sosial yang tinggi. Ungkapan memerinntah yang seperti ini biasanya ditemui pada situasi kebahasaan yang tidak formal, atau dituturkan oleh seorang pimpinan kepada seorang pesuruh, oleh seorang ibu kepada pembantunya, seorang guru kepada muridnya.

Berbeda jika situasi pertuturan berlangsung dalam situasi formal dan tidak akrab, kemudian ungkapan seperti pada (4b,5b, dan 5b) dituturkan oleh seorang yang memiliki status sosial yang rendah dan ditujukan kepada mitratutur yang memiliki status sosial yang tinggi dan merupakan orang yang dihormati maka ungkapan memerintah tersebut dianggap sangat kasar dan tidak santun. Selain situasi pertuturan seperti itu dapat mengancam muka mitratutur, tujuan atau maksud penutur meminta bantuan kepada mitratutur akan sulit terwujud. Dalam konteks seperti ini, mitratutur akan merasa sangat direndahkan dan merasa sangat tidak dihormati oleh penutur.

\subsection{Memerintah Secara Eksplisit dengan Maksud Melarang}

(7) Ajakna mupangngoloi anrimmu akki yolona babangnge, macekke $i$ matuk!

'Jangan kamu hadapkan Adik kamu di depan pintu, dingin dia nanti!'

(Jangan kamu hadapkan adikmu di depan pintu, nanti dia kedinginan!)

(8) Ajakna taingngerrangngi emma'mu nak, malasa ammakik!

'jangan kamu ingat mama kamu nak, sakit nanti kamu!

(Nak, jangan ingat mama kamu lagi, nanti kamu sakit!)

(9) Ajak memengna mujokka akki bolana na, napeddiriko situ matu! 'Jangan memang kamu pergi di rumah dia ya, dia akan memukulmu lagi!'

(Jangan lagi kau ke rumahnya, ya. Nanti dia memukul kamu!)

Strategi memerintah secara eksplisit yang diwujudkan dalam bentuk melarang pada tuturan (7-9) dipilih agar lebih memudahkan kemungkinan terjadinya kerjasama lebih tinggi antara penutur dan mitratutur. Ungkapan memerintah pada tuturan tersebut dianggap memiliki kadar kesantunan yang normatif. Dengan menggunakan pemarkah kesantunan ajak 'jangan' yang secara tidak langsung berfungsi sebagai pelembut ujaran, sehingga ungkapan perintah tersebut dapat dengan mudah 
berterima dan tidak menimbulkan ketersinggungan mitratutur. Sementara itu, ungkapan memerintah tersebt dapat dianggap sebagai tuturan yang memiliki kadar kesantunan yang normal. Maksudnya, karena ungkapan tersebut dituturkan sesuai kebiasaan yang berlaku dalam masyarakat Bugis khususnya yang ada di Kabupaten Wajo. Penggunaan kata ganti orang pertama tunggal $m u$ - pada kata mupangngoloi 'kamu hadapkan' dan penanda kategori fatis - $-m u$ pada anrimmu 'adikmu' dan - $k o$ sebagai kata ganti orang ketiga tunggal pada kata napeddiriko 'dia memukulmu'. Jadi penggunaan pemarkah di atas wajar digunakan oleh penutur ungkapan pada (7-9).

\section{Strategi Memerintah Secara Implisit}

\subsection{Memerintah Secara Implisit} dengan Maksud Melarang

(10) Malessi laddekkik, Pak.

'Cepat sekali kamu, Pak.'

(Terlalu laju, Pak.)

(11) Buru'ni tu karoppo'e akko Tatenre'wi

'Hancur sudah kerupuknya kalau kamu tekan'

(Akan semakin hancur kerupuknya kalau kamu tekan lagi)

Strategi memerintah secara tidak langsung tersebut di atas merupakan startegi yang paling sederhana. Namun demikian untuk memaknai kalimat yang seperti ini antara penutur dan mitratutur maka keduanya harus memahami konteks pembicaraan, sebab ika tidak maka akan terjadi kesalahpahaman di antara kedua belah pihak.

Demikian halnya pada tuturan (10) penutur bermaksud melarang Bapaknya mengendarai motornya dengan laju, karena dia merasa takut. Agar perintah larangan itu tidak langsung, maka penutur menggunakan kalimat malessi laddekkik, Pak 'cepat sekali kamu, Pak'.
Begitupun pada tuturan (11), penutur bermaksud melarang anaknnya menekan kerupuk yang ada di dekatnya itu. Kata buru'ni tu 'semakin hancur'.

\subsection{Strategi Memerintah Secara Implisit dengan Maksud Menyuruh \\ (12) Goncing motoroktak, Daeng 'Kunci motor kamu, Kak (Kunci motormu, Kak) \\ (13) Safwan, labuni essoe! 'Safwan, Magrib sudah!' (Safwan, sudah magrib!) \\ Dalam pemakain bahasa Bugis} keseharian, tuturan mmemerintah yang diwujudkan dalam bentuk menyuruh yang secara implisit seperti pada tuturan (1213) di atas dapat diketahui makna atau tujuannya melalui konteks dan situasi pertuturan yang melatarinya, termasuk kesepahaman dan kerjasama yang baik antara penutur dan mitratutur. Kalimat perintah goncing motoroktak 'kunci motor kamu' (12) dapat ditafsirkan sebagai perintah suruhan agar mitratutur tidak lupa mengambil kunci motor yang diletakkan di meja. Selain itu juga adanya penggunaan kata ganti milik orang pertama tunggal $-t a k$ dan penanda honorifik daeng 'kak' pada tuturan itu yang semakin menambah tingginya kadar kesantunan tuturan tersebut. Begitupula pada tuturan (13) yang diungkapkan oleh seorang nenek kepada cucunya, merupakan tuturan perintah secara implisit. Dengan menggunakan kata labuni essoe 'sudah magrib' diharapkan mitratutur dapat menafsirkan maksud neneknya agar ia segera masuk ke dalam rumah karena hari sudah magrib.

\section{b. Pembahasan}

Data yang diperoleh dari hasil pengamatan penulis mengenai strategi kesantunan bahasa Bugis dalam tindak memerintah di masyarakat Desa Lamata Kecamatan Gilireng Kabupaten Wajo 
tersebut dianalisis dengan menggunakan pendekatan pragmatik. Dalam proses penganalisaan ini, penulis menggolongkan dua jenis strategi kesantunan dan kedua jenis ini terbagi lagi dalam beberapa bagian. Banyak ungkapan atau tuturan memerintah yang berhasil penulis amati, namun penulis hanya menganalisis sebagian saja dari data yang diperoleh karena keterbatasan waktu dan kemampuan yang penulis miliki.

Berdasarka data yang diamati, diperoleh gambaran bahwa tindak tutur memerintah antara masyarakat yang satu dengan masyarakat yang lain di Desa Lamata cenderung memiliki kadar kesantunan yang berbeda dan memiliki pula strategi yang berbeda dalam menuturkan ungkapan perintah yang disampaikan kepada mitratutur.

Bentuk tuturan memerintah yang dituturkan oleh seseorang dengan yang lainnya cenderung sama, hanya saja penggunaan strategi, pemarkah, penggunaan penanda kategori fatis dan bahkan tekanan berbahasa terdapat perbedaan.

\section{SIMPULAN}

Kajian tentang Strategi

Kesantunan Bahasa Bugis dalam Tindak Tutur Memerintah di Desa Lamata Kecamatan Gilireng Kabupaten Wajo menunjukkan berbagai hasil yang dapat disimpulkan menjadi bagian sebagai berikut:

1. Ada dua strategi utama yang digunakan oleh penutur dalam memerintah, yaitu ungkapan secara eksplisit (langsung) dan secara implisit (tidak langsung). Dari keseluruhan bentuk strategi yang digunakan ditemukan ada enam belas (16) strategi ungkapan memerintah yang digunakan oleh pennutur bahasa Bugis yang ada di Kabupaten Wajo. Dalam hal ini ada sebelas (11) strategi memerintah secara eksplisit dan lima (5) strategi memerintah secara implisit. Sebelas strategi memerintah secara eksplisit tersebut di klasifikasikan berdasarkan maksudnya, yaitu: (1) menyuruh, (2) meminta, (3) melarang, mengizinkan, (5) mengimbau, (6) menganjurkan, (7) mengharapkan, (8) mengajukan, (9) mempersilakan, (10) mengajak, dan (11) mendesak. Sedangkan lima strategi memerintah secara implisit yang juga diklasifikasikan berdasarkan maksud, yaitu: (1) melarang, (2) menyuruh, (3) meminta bantuan, (4) mengimbau/mengajak/mendesak, dan (5) memohon/permisi.

2. Berdasarkan pada pemilihan strategi yang digunakan oleh penutur menunjukkan bahwa dalam mengungkapkan perintahnya, penutur bahasa Bugis yang ada di Kabupaten Wajo cenderung diungkapkan secara eksplisit dengan pemarkah tertentu yang sangat berperan dalam menentukan kadaritas kesantunan atau tingkat kesantunan ungkapan dalam memerintah. Penutur mengunkapkan perintahnya dengan menggunakan (1) verba tertentu seperti tulungngak, tabek, taddapengekkak, (2) kata berkategori fatis, $-k u k, m u,-n a$, dan sebagainya (3) penanda honorifik yang mengacu pada hubungan kekerabatan puang, ndik, daeng, nurek, nak, dan sebagainya serta (4) penggunaan kosa kata tertentu. Ditemukan pula indikator atau pemarkah lain seperti garek 'coba', weddimmua 'boleh saja', dan sebagainya.

\section{DAFTAR PUSTAKA}

Akbar Muh. 2014. Analisis Tindak Tutur dan Gaya Bahasa Ceramah Ustadz Nur Maulana. Skripsi 
tidak diterbitkan. Unismuh Makassar.

Austin, J.L. 1962, How to Do Things with Words. New York: Oxford Universitas Press.

Harnida. 2012. Tindak Tutur Karyawan di Lingkungan Perusahaan PT. Katingan Timber Celebes (PT. KTC) Kecamatan Biringkanaya Kota Makassar. Skripsi tidak diterbitkan. Unismuh Makassar.

Hasbia, K. 2012. Strategi Tindak Tutur Penyiar dalam Acara Harmoni Pagi Radio PLS
100,0 FM Makassar (Suatu Tinjauan Pragmatik). Skripsi tidak diterbitkan. Makassar: Unismuh Makassar.

Leech, G.N. 1993. Principles Of Pragmatics. New York: Longman.

Leech. Geoffrey. 1983. Prinsip-Prinsip Pragmatik. Dialibahasakan oleh M.D.D.Oka. Jakarta: Universitas Indonesia Press.

Sumarsono. 2002. Sosiolinguistik. Yogyakarta: Pustaka Pelajar.

Yule, George. 2006. Pragmatik. Yogyakarta: Pustaka Pelajar. 